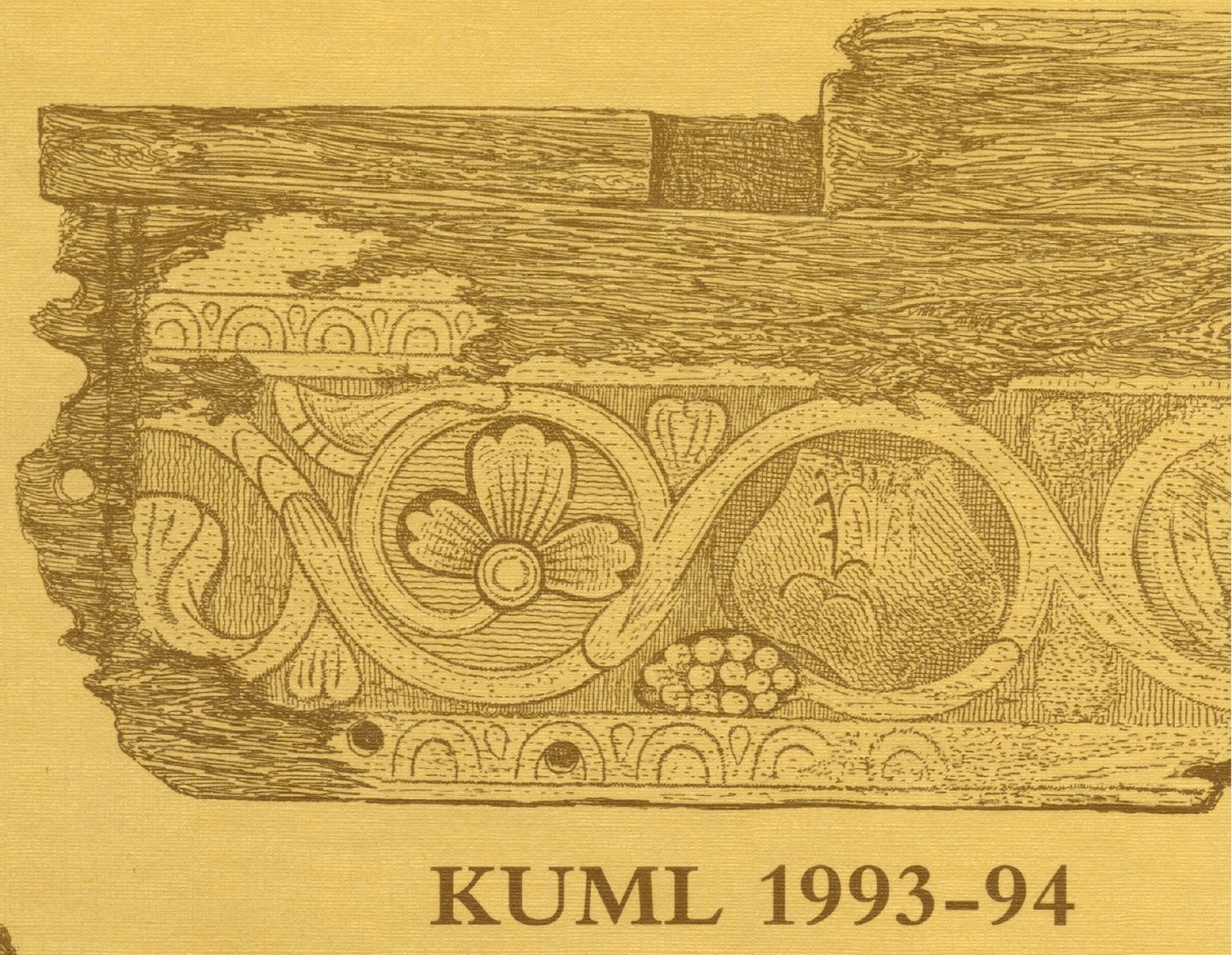




\section{KUML 1993-94}

Årbog for Jysk Arkæologisk Selskab

With summaries in English 
Redaktion: Hans Jorgen Madsen, Poul Kjarum og Birgit M. Rasmussen

Redaktionsudvalg:

Steen W. Andersen, Haderslev

Jens Henrik Bech, Thisted

Steen Hvass, Vejle

Stig Jensen, Ribe

Erik Johansen, Aalborg

Carsten Paludan-Müller, Randers

Ole Schiorring, Horsens

Lay-out og omslag: Jørgen Mührmann-Lund

Grafisk tilrettelagggelse: Elsebet Morville

Tryk: Narayana Press

Skrift: Bembo 11/12

Papir: $115 \mathrm{~g}$ Artik Silk

Copyright 1996 by Jysk Arkaologisk Selskab

ISBN 87-7288-585-8

ISSN 0454-6245 


\section{Indhold/Contents}

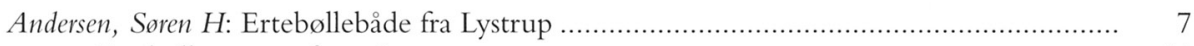

Ertebølle canoes from Lystrup ....................................................................... 36

Ebbesen, Klaus: En jættestue ved Fjersted, Sydvestjylland......................................... 39

A Passage Grave at Fjersted, SW Jutland ................................................... 85

Hansen, Mogens: Træbyggede gravkister fra Enkeltgravskulturen og Senneolitikum ........... 87

Wooden burial cists from the Single Grave Culture and the Late Neolithic .............. 145

Nilsson, Torben: Store Tyrrestrup

En vendsysselsk storgård med bronzedepot fra ældre bronzealder............................ 147

Store Tyrrestrup. A large Early Bronze Age farmstead with bronze hoard .............. 153

Anne-Lonise Haack Olsen og Jens-Henrik Bech. Med bidrag af Svend Th. Andersen,

Pia Bennike, Kjeld Christensen og David Earle Robinson: Damsgård

En overpløjet høj fra ældre bronzealder per. III med stenkiste og ligbrændings-

grube .....

Damsgård. A ploughed-over barrow from Early Bronze Age Per. III with

stone cist and pyre-pit.

Aase Gyldion Andersen: Frugtbarhedsofringer i Sydvestfyns ældre jernalder

Private eller kollektive ofringer?

Fertility Sacrifices in the Early Iron Age of SW Funen. - Private or Collective?..... 210

Torben Egeberg Hansen: Et jernalderhus med drikkeglas i Dejbjerg, Vestjylland .................. 211

Drinking Glasses from an Iron Age settlement from Dejbjerg, West Jutland.............. 237

Mette Iversen og Bjarne H. Nielsen: Brandstrup III.................................................... 239

Grave fra yngre romersk jernalder

Brandstrup III. Graves from the Late Roman Iron Age...................................... 250

Anne Hedeager Krag: Smykkefundet fra Lerchenborg ............................................. 251

Østlige forbindelser i vikingetid

The Lerchenborg Ornaments. Eastern connections in the Viking Age ................ 261

Jens Jeppesen og Holger Schmidt: Rekonstruktion af stavkirken fra Hørning ....................... 263

The reconstruction of the stave church at Hørning ............................................... 275

Bruno Frohlich, Henrik Hjalgrim, Judith Littleton, Niels Lynnerup og Birgitte Sejrsen:

Skeletfundene fra Skt. Peders sognekirkegård i Randers ......................................... 277

Skeletal remains from St. Peder's parish church in Randers .................................. 287

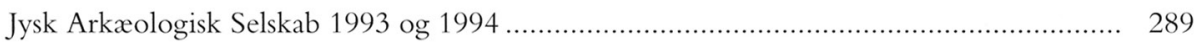




\title{
Smykkefundet fra Lerchenborg Østlige forbindelser i vikingetid
}

\author{
Af Anne Hedeager Krag
}

I de senere år er de østlige kontakter i vikingetiden blevet fremhævet, og det sker med god grund, idet de skandinaviske fund i Rusland fra vikingetid langt overgår antallet af skandinaviske fund fra samme periode i Vesteuropa (Andersen \& Birkebæk 1993, 5). Der er mange årsager til, at kendskabet til de vigtige arkæologiske kilder i Rusland tidligere har spillet en mindre rolle i opfattelsen af vikingetiden, men nye udgravninger i Rusland samt nye publikationer af de svenske Birka-fund viser, at også den danske vikingetid har modtaget mange påvirkninger østfra. I det følgende vil et dansk fund blive diskuteret i relation til disse østlige forbindelser.

For godt 100 år siden, i 1889, blev der gjort et stort smykkefund i nærheden af Lerchenborg ved Kalundborg. Oldsagerne blev fundet af J.C. Pedersen og Hans Olesen i Asnæs Dyrehave under grevskabet Lerchenborg, og de afleveredes til Lensgreve Lerche, der videregav dem til Nationalmuseet. Genstandene var fundet godt en halv meter nede i en grusgrav på en flad mark, som tidligere havde været en del af havet og kun lå 0,60-1 m over dets overflade.

Fundet består af følgende genstande (1) (fig. 1): To skålformede spænder, et aflangt sølvspænde med filigranmønster, en rund sølvplade med bronzeøsken og med ornamentik af indlagte niello-mønstre, to tenformede sølvperler, en oval sølvperle med S-formede filigranspiraler, en perle dannet af spirallagt bronzetråd, brudstykke af sølvhalskæde bestående af sammenflettede sølvtråde og med en lille øsken i den ene ende, 42 perler af glas og mosaik og karneol. Perlerne har sandsynligvis tilhørt en halskæde, men syv af dem er trukket på tre særskilte sølvtråde, der er lukket ved snoning, fire mønter, heraf en frankisk, slået af Ludvig d. Fromme, 814-40, med sekundær øsken, så den kunne anvendes som hængesmykke, samt to kufiske mønter, dateret til 700-800 årene. Endelig en nordisk kopi af den mønttype, Karl d. Store lod slå i Dorestad (Neergaard 1892, 207ff; Skovmand 1942, 107ff; Ramskou 1976, 80).

Genstandene fandtes samlet imellem de to skålformede spænder, der lå med randen mod hinanden. Samme nedlægningsmåde kendes fra et norsk fund fra Haugen i Jarsberg Amt (Neergaard 1892, 323). Mønterne har allerede på nedlægningstidspunktet været gamle, for de to skålformede spænders form og ornamentik daterer fundet til 900-årene e.Kr.

Umiddelbart efter indlevering af fundet på Nationalmuseet opfattedes det som et gravfund. Neergaard noterer: "Ved benlevninger var det efter Sigende ogsaa, at der i en Grusgrav under Grevskabet Lerchenborg, Aarby Sogn, Holbæk Amt, i 65 cm's dybde optoges to dobbelskallede, skaalformede Spænder, begge med forgyldt Dækplade og fem giennembrudte Knopper« (Neergaard 
1892, 323). Tilsyneladende var der således bevaret skeletrester i forbindelse med genstandene, men senere er de forsvundet, og der har været livlige diskussioner, om der er tale om et gravfund eller et depotfund (Neergaard 1892, 323; Brøndsted 1936, 202; Skovmand 1942, 107f; Ramskou 1976, 77f; Callmer 1977, 13; Bender Jørgensen 1986, 223). Uanset hvilken fundkategori der er tale om, viser fundet et samlet dragt- og smykkeudstyr tilhørende en kvinde.

\section{Fundets smykker}

De to skålformede spænder tilhører typen P 51, som dateres til 900-årene (Petersen, 1928, 59; Jansson 1985, 182). Skålformede spænder er karakteristiske skandinaviske dragtsmykker, og deres udbredelse strækker sig fra de skandinaviske bebyggelser i Irland og Island mod vest til Dnepr- og Volgaområdet i øst (Gjessing 1934, 159ff). Skålformede spænder optræder for første gang i Danmark i yngre germansk jernalder, Ørsnes' fase $3 \mathrm{~A}$, det vil sige tiden omkring 725 e.Kr. (Ørsnes 1966, 224).

I 700-årene er spænderne mindre end i 800- og 900-årene, og de er mere individuelt udformede og prydet blandt andet med dyreornamentik. I 800-årene slår en standardisering igennem, så spænderne bliver større, sædvanligvis over $10 \mathrm{~cm}$ lange og kraftigt hvælvede. Ornamentikken er ofte reliefmønster. Endelig er 900-årenes skålformede spænder normalt dobbeltskallede med ornamentikken helt eller delvist placeret på en gennembrudt overskal. Spænderne er ofte forgyldte og kan være belagt med hvidmetal, sølvpresblik og sølvsnoninger (Jansson 1985, 13). Alle kendte skålformede spænder er udført i bronze, lige med undtagelse af et par fra Hedeby, der er lavet af sølvblik med filigranmønstre (Steuer 1974, fig. 17:1). I 1000-årene var spænderne faktisk gået af brug i Skandinavien, men de blev dog fortsat benyttet i Finland og i områderne omkring Ladoga-søen samt Letland, hvor de har givet inspiration til små, oftest spidsovale spænder, der tilhører sen vikingetid og tidlig middelalder (Jansson 1985, 13). Parvise spænder anvendtes i forbindelse med datidens selekjole.

Der kendes ca. 400 skålformede spænder i det sydskandinaviske område, som omfatter Danmark, Hedeby og Skåne (Hedeager Krag 1994, 17). Det er kun en lille del i forhold til antallet i Norge og Sverige, hvor der er fundet over 3000 skålformede spænder (Jansson 1985, 12). Udbredelsen har været nordøstligt orienteret i Skandinavien, og selekjolen med de skålformede spænder må således betragtes som en skandinavisk dragtskik, der især er udbredt i de nordøstlige egne.

Typen P 51, som Lerchenborgfundets spænder tilhører, er den altdominerende type i 900-årene i hele Skandinavien (Jansson 1985, 81). Ud af 102 eksemplarer i Sydskandinavien tilhører 75 eksemplarer typen P 51. Med andre ord er ca. 75\% af de skålformede spænder fra 900-årene i Sydskandinavien af typen P 51 (Hedeager Krag 1994, 36) (fig. 2).

Lerchenborgfundets smykkeudstyr adskiller sig radikalt fra andre danske gravfund med skålformede spæender fra 900-tallet på grund af sit markante indhold af importsager. Især skal den flettede halskæde med bl.a. en mønt som vedhæng fremhæves, for brugen af vedhæng viser tydeligt forbindelser mod øst. I Birka er der ligeledes fundet vedhæng i gravfund med skålformede spænder. Fra syv Birkagrave kendes ialt 14 vedhæng fastgjort på flettede halskæder (Duczko 1985, 32). 
Fig. 1. Lerchenborgfundet (Skovmand 1942, 109).

The Lerchenborg find.

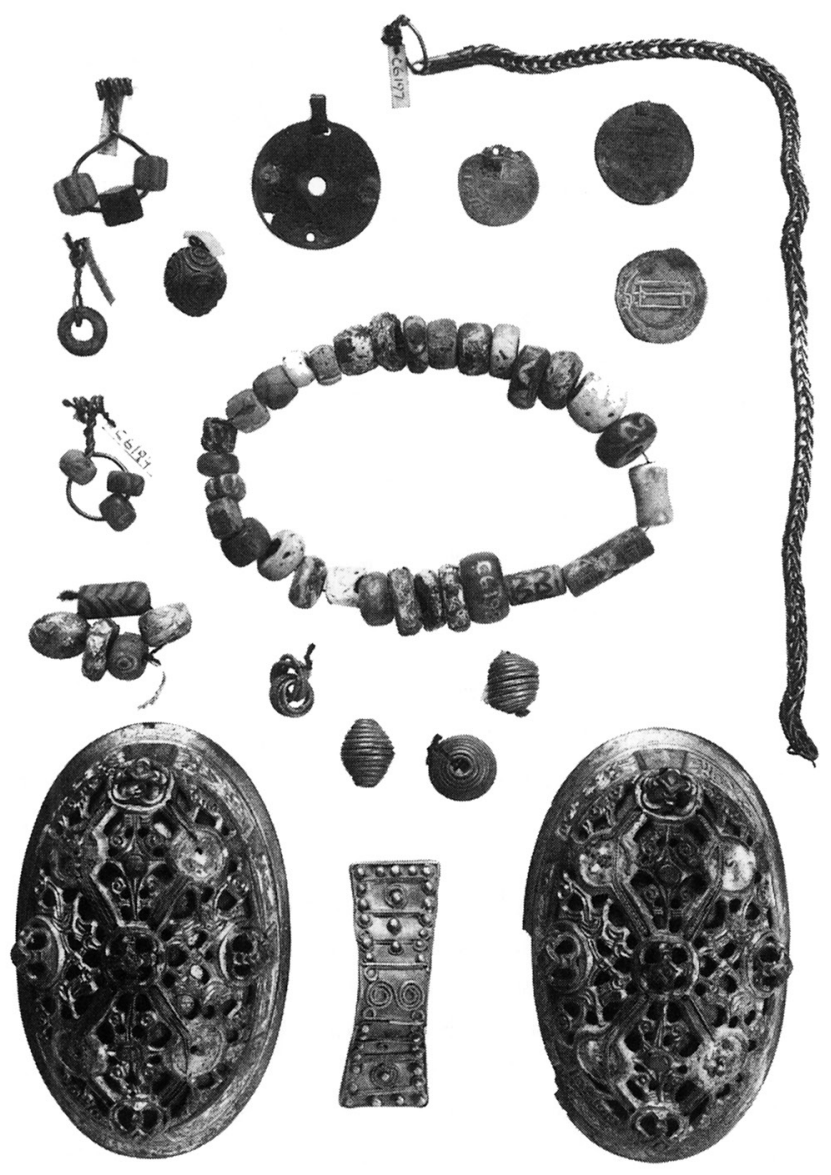

Et af sølvsmykkerne i Lerchenborgfundet er et rundt vedhæng med øsken. Diameteren er 3,2 cm, og det har fem symmetrisk anbragte huller, hvoraf et i midten, resten ved kanterne. Pladens forside er ornamenteret med dobbeltspiraler, der er forbundet med tværbånd, kranse m.m. De fordybede linjer er indlagt med niello. Overfladen bærer spor af let forgyldning. Det runde sølvvedhæng er i motiv og stil beslægtet med de runde hængesmykker i Terslevfundet (Friis Johansen 1912, 226ff; Skovmand 1942, 110), men Terslevsmykkerne er alle prydet med filigranornamentik. Terslevspændernes udbredelse strækker sig især i det sydøstlige Skandinavien med enkelte fund i Nordtyskland og i det baltiske område (Capelle 1968, 80 og kort 30).

Desuden er der et aflangt smykke af sølv i Lerchenborgfundet, $6,1 \mathrm{~cm}$ langt og $2,5 \mathrm{~cm}$ bredt. Det buer opad på midten, og oversiden er prydet med påloddede kugler langs randen samt filigrantråde, der danner bælter på tværs af pladen. På midten er anbragt en S-spiral (Skovmand 1942, 107-108). Smykket er helt glat på bagsiden. Der er kun ganske fă paralleller dertil, men blandt andet fra en af Birkagravene kendes et sølvspænde med filigranmønster ligesom sølvsmykket fra Lerchenborg (Arbman 1938, 198ff; Arbman 1940, Taf. 83, 1a-b). 


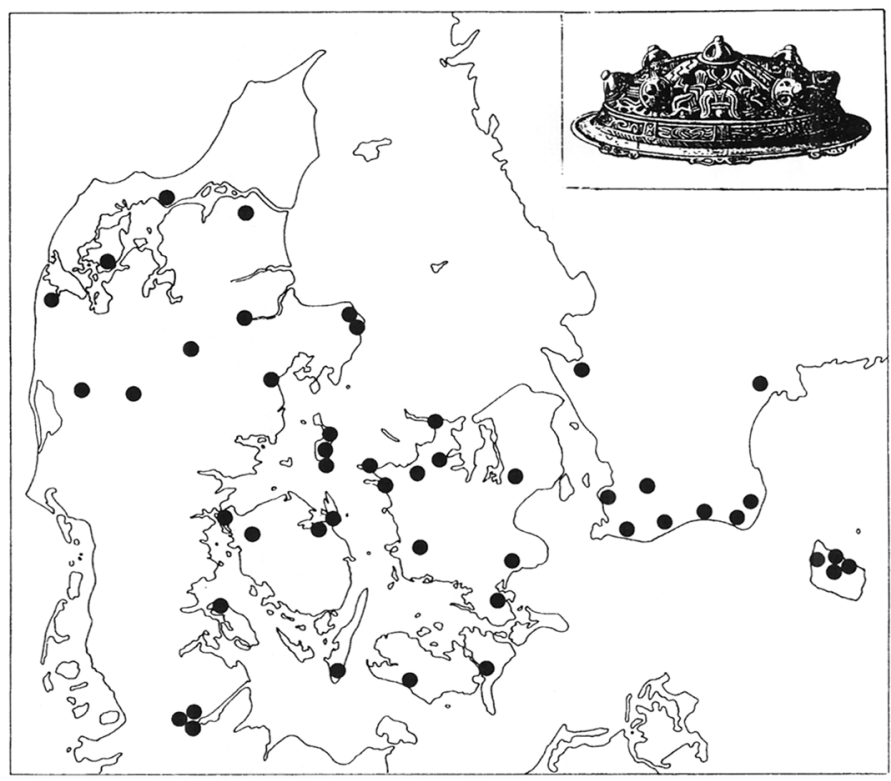

Fig. 2. Udbredelseskort over skålformede spænder af typen P 51.

The distribution of tortoise brooches of type P 51.

Et andet usædvanligt træk i Lerchenborgfundet er det store antal perler, hvoraf 41 er af glas og mosaik og en er af karneol (Skovmand 1942, 107-108; Callmer 1977, 12). Syv af perlerne er trukket på tre særskilte sølvtråde, der er lukkede med en snoning. Karneolperlen er afbildet på fig. 1 øverst til venstre som den midterste perle. Karneolperler kendes i skandinaviske vikingetidsfund især fra Birka og Hedeby, hvorimod de er sjældne i danske vikingetidsfund; et eksemplar kendes dog fra Fyrkat. Karneolperler menes at være fremstillet på værksteder i Kiev, og deres udbredelse følger de russiske flodveje til Nord- og Mellemeuropa. Alt tyder således på, at karneolperlen i Lerchenborgfundet er importeret østfra.

I Lerchenborgfundet er der endvidere tre sølvperler. De to er tenformede og dannet af spiralsnoet sølvtråd, og den tredje er oval prydet med S-formede filigranspiraler. Omtrent 70 eksempler af denne filigranprydede perletype kendes fra skatte- og gravfund i de skandinaviske lande, de baltiske stater og i Rusland (Duczko 1985, 73f). Størstedelen af disse perler kendes fra det centrale og østlige Sverige inklusiv Gotland. Endelig indeholder Lerchenborgfundet en lille kegleformet perle, dannet af spirallagt bronzetråd, $1 / 2 \mathrm{~cm}$ i diameter (Skovmand 1942 , 107-108). Oftest findes der mellem to og otte perler i gravfund fra 900-årene i Danmark, dog med undtagelse af Bornholm (2). Til den gotlandske kvindedragts smykkeudstyr hørte tit et stort antal perler i vikingetid (Munksgaard 1974, 172). Ligeledes ses $\mathrm{i}$ det svenske bådgravfelt Tuna, grav VI (Arne 1934, Taf XI) en perleopsætning med to skålformede spænder, der har ligheder med Lerchenborgfundet. Interessante er også vedhæng bestående af snoede sølvringe med en perle (fig. 3). Det kan tænkes, at de tre perlevedhæng i Lerchenborg har haft lignende ophængningsmåde. Tilstedeværelsen af mange perler i et dragtsmykkeudstyr tyder således på, at der er tale om en østlig inspiration. 


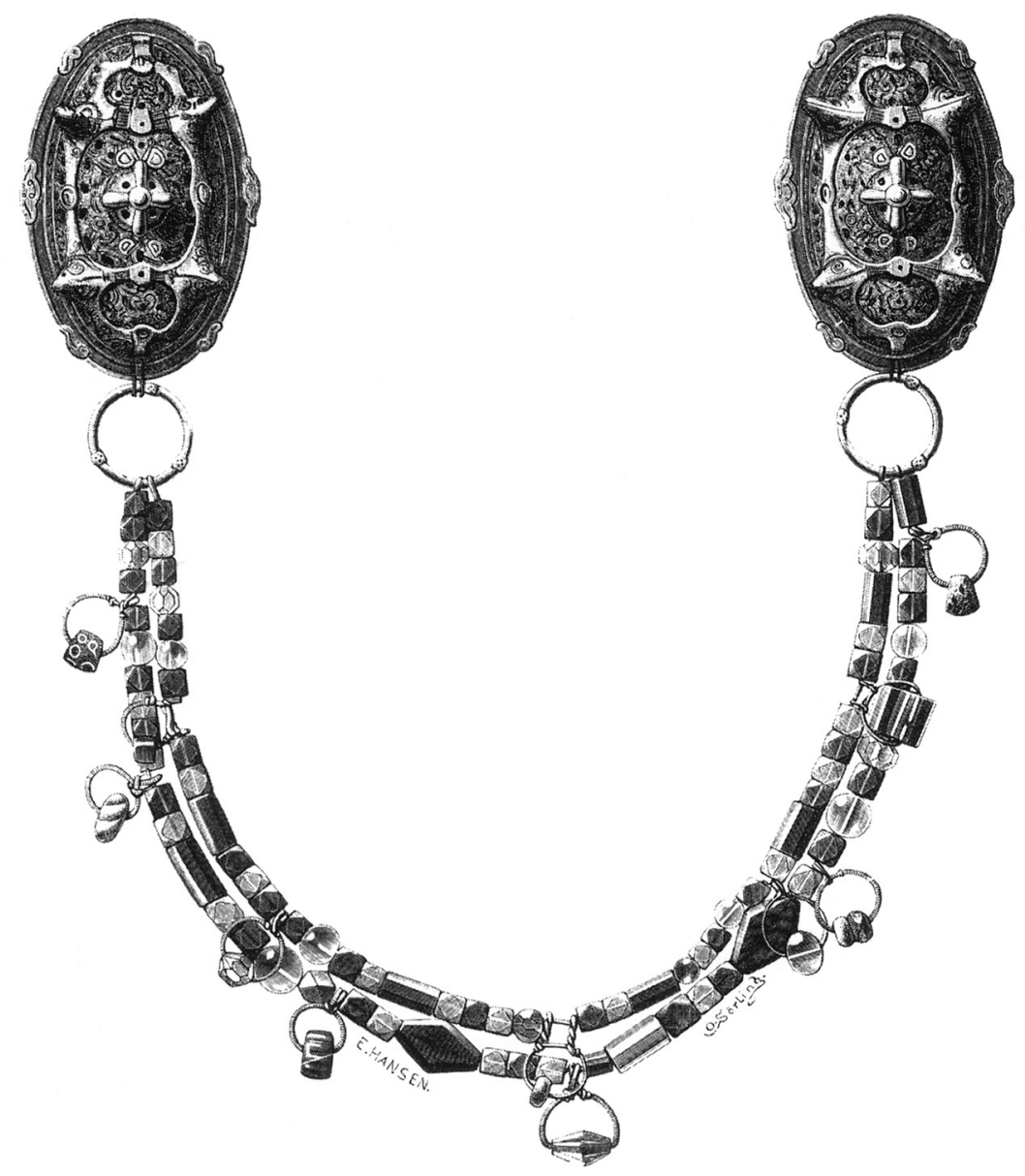

Fig. 3. Smykkeophæng fra Tuna, grav VI (Arne 1934, Taf. XI).

The suspended ornaments from Tuna grave VI.

Til Lerchenborgfundet hører fire sølvmønter, der er anvendt sekundært som vedhæng; heraf er de tre afbildet på fig. 1. To af mønterne er vesteuropæiske, og to er kufiske. Som tidligere nævnt var Lerchenborgfundets mønter gamle, da de blev nedlagt med de øvrige smykker. Mønterne er vigtige som historisk kilde til vikingetiden, for som regel oplyser de både om tid og sted for deres prægning (Malmer 1991, 209ff). Importen af orientalske mønter til Skandinavien begyndte i 800-årene og nåede sit højdepunkt i midten af 900-årene; derefter ebbede importen ud og ophørte totalt 1010-1020, herefter blev de europæiske mønter helt dominerende (Asingh \& Kromann 1992, 157). I et lille antal danske vikingetidsgrave kendes mønter, hvor der som i Lerchenborgfundet, er øsken eller huller i mønterne til ophængning. I kvindegraven fra Hvilehøj ved Randers, dateret til 900-årene, blev fundet en tysk mønt præget under Otto d. I, 936-962, ligeledes anvendt sekundært som vedhæng i halskæde (Engelhardt 
1881, 180). I vikingetidsgrave på Langeland kendes desuden et par eksempler med mønter anvendt dels som betalingsmiddel, dels i en ceremoniel sammenhæng (Grøn m.fl. 1994, 134f).

\section{Tolkning og diskussion af fundet}

Både sølvsmykkerne, den flettede halskæde med vedhæng og perlerne viser som nævnt Lerchenborgfundets forbindelse til Sverige og Rusland. I Rusland giver forbindelserne med Skandinavien sig til kende på flere måder, blandt andet i fundene ved byen Gnezdovo og i området ved floden Dnejpr's udspring. Fundene viser typiske slaviske og skandinaviske typer fra samme gravfelter og i samme skattefund. Især skal fremhæves skattefundet fra Gnezdovo, som indeholdt filigransmykker og runde hængesmykker, der anses for at være et skandinavisk fænomen, hovedsagelig svensk. Blandt de slaviske smykker dominerede perler og halvmåneformede vedhæng med granulation, som er små påloddede metalkorn. Skattefundet ved Gnezdovo var stort med over 120 smykker og mønter, og det dateres til 900-tallet (Duczko 1989, 12).

Gnezdovo-fundet vidner tydeligt om en blanding af russiske og skandinaviske kulturer. Netop i vikingetiden var de russiske floder Dnejpr og Volga vigtige transportveje for skandinaviske vikinger. Floden Dnejpr gik til Sortehavet, hvorfra transporterne gik videre til Konstantinopel, som var et betydeligt magtcentrum i 900-årene. Den romerske kejser gjorde år 330 Konstantinopel, det nuværende Istanbul, til Romerrigtets anden hovedstad, Nova Roma. Da Det Vestromerske Rige, styret fra Rom, 150 år senere faldt for germanerne, blev Konstantinopel Det Byzantinske Riges hovedstad, og forblev det i 1000 år, indtil tyrkerne erobrede området i 1453 (Bouchér 1967, 145ff).

Konstantinopel spillede en vigtig rolle i datidens handel og økonomi. Byen havde frie forbindelser med Orienten, og i yngre jernalder og vikingetid blev Konstantinopel knudepunkt for både frankernes og skandinavernes handel med Orienten. En af de mest eftertragtede handelsvarer i Konstantinopel var silke, der $\mathrm{i}$ begyndelsen kom ad karavanevejene fra øst, men senere blev fremstillet i området omkring byen (Boyer 1957, 179). Karavaneruten, eller som den også kaldes, Silkevejen, strækker sig fra Kina i øst, tværs gennem Asien til det østlige Middelhavsområde (Myrdal 1978, 5ff).

I Sverige er der i Birkagravene blandt de bevarede tekstilfragmenter fundet guld- og sølvtråde samt silke. Gravene stammer fra en befolkningsgruppe, der tilhører et højt socialt lag i den svenske vikingetidskultur. De eksklusive textiler i Birka er tidligere blevet tolket som værende luksusvarer, som de enkelte vikinger erhvervede sig ved handel mod øst (Geijer 1938). Senere tolkninger antyder, at disse luksusvarer i Birka ikke blot er tegn på velstand. Silke-, guldog sølvtrådsarbejderne er også udtryk for symbolske elementer i en dragt tilhørende personer i samfundets højeste klasser (Hägg 1984, 210; 1991, 155).

I Birka er der mange fund, der vidner om den nære kontakt, svenske vikinger havde øst- og sydpå, og byen anses for at have været et vigtigt handelscentrum, hvor de skandinaviske og nærorientalske varer blev udvekslet. Lerchenborgkvinden kan altså have haft en nær forbindelse med den magtfulde købmandsbefolkning i Østsverige og derved have erhvervet sig de fremmede dragtsmykker og øvrige smykkeudstyr. Måske kunne hun selv være fra Birka. 
Guldtråde og silke i en halv snes danske gravfund fra 900-årene viser, at de gravlagte personer har hørt til samfundets øverste lag (Munksgaard 1974, 173ff). De har antagelig haft politisk magt, og derved været med til at forme det danske samfund, der i 900-årene undergik store forandringer. I Jylland har der tilsyneladende været et magtcentrum, der giver sig til kende med fund af eksklusive dragtelementer blandt andet i Mammen ved Viborg og i Jelling (Iversen \& Näsman 1991, 52). I Mammen-graven er der fundet righoldige textiler, der i teknik og mønster peger mod frankisk-byzantinske hofkredse (Hedeager Krag 1989, 357). I samme grav fandtes dog også ti små hængesmykker af guldblik, som menes at være dele af et hængesmykke, der er hjemmehørende i Rusland (Duczko 1989, 14). Senest er de sat i forbindelse med et østeuropæisk herskermiljø (Iversen \& Näsman 1991, 51). Sådanne smykker kendes fra området mellem Staraja Ladoga og Gnezdovo, de to nævnte lokaliteter var jo netop vigtige stationer på vikingernes flodrejser i Rusland.

På Fyn var der ved Kerteminde sandsynligvis også et mindre magtcentrum, hvorfra kendes den rige skibsbegravelse fra 900-årene, Ladbyskibet (Thorvildsen 1957). Orientalsk indflydelse i dragten fra Ladby ses ved sølvtrådspossementer, som er en slags knapper til en tunika. Også Ladbydragtens karakter anses for at være rangbetegnende. Dragten opfattes som en slags embeds- eller hofdragt, der direkte er inspireret fra det russiske hof i Kiev (Iversen \& Näsman 1991, 51). Fra Fyn kendes desuden den store kammergrav i Søllested (Brøndsted 1936, nr. 80), der også er fra 900-årene. Sammen med Ladbyskibet antyder Søllestedfundet, at personer med stor magt og rigdom boede på Fyn i 900-årene. På Sjælland var der ved Slagelse højst sandsynlig et magtcentrum med Trelleborg (Nørlund 1948), som det politisk-økonomiske samlingspunkt i sidste halvdel af 900-årene.

Desværre er der ikke bevaret tekstiler i Lerchenborgfundet; men i Slotsbjergby ved Slagelse, ca. $30 \mathrm{~km}$ fra Lerchenborg, blev der i begyndelsen af 1890'erne fundet guldtråde og fragmenter af fint klæde. I Nationalmuseets protokol er de indført således: »9166. Nogle Læderrester, Dels af fint Tøj lavet af snoede Silke (?)traade og indvirket med Guldtraad, i alt ca. 10 Kvadratcm., stærkt medtaget«. Materialet er senere bestemt til at være en kantning af et stykke klæde, der formentlig er brikvævet (Hald 1980, 118-119).

Lerchenborgkvinden kan have haft sine forbindelser med det magtfulde miljø, der fandtes i 900-årenes Danmark. På grund af de manglende tekstiler i fundet kan dragtens udseende ikke rekonstrueres. Sandsynligheden taler dog for, at kvinden har båret en dragt, der ikke afviger fra den gængse kvindedragt i vikingetiden. Dragtsmykkerne, og specielt de skålformede spænder antyder, at der er båret en dragt, bestående af en selekjole, der blev holdt oppe med de to spænder. Til dragten hørte udover selekjolen, der ofte var fremstillet af uld, en underkjole eller en særk, der ihvertfald i Birka ofte var af hør (Hägg 1974, 51). Endelig havde dragten også en kappe, ligeledes fremstillet af uld, og den kan være pyntet med et bånd af silke med guld- og sølvtråde. Den blev båret over kjolerne og blev holdt sammen med et enkelt spænde. I Lerchenborgfundet kan det aflange sølvsmykke være brugt som spænde for kappen.

Smykkeudstyret fra Lerchenborg kan have sine paralleller i de byzantinske dragtsmykker, der kendes fra mosaikker i San Vitale i Ravenna, Italien (Deich- 


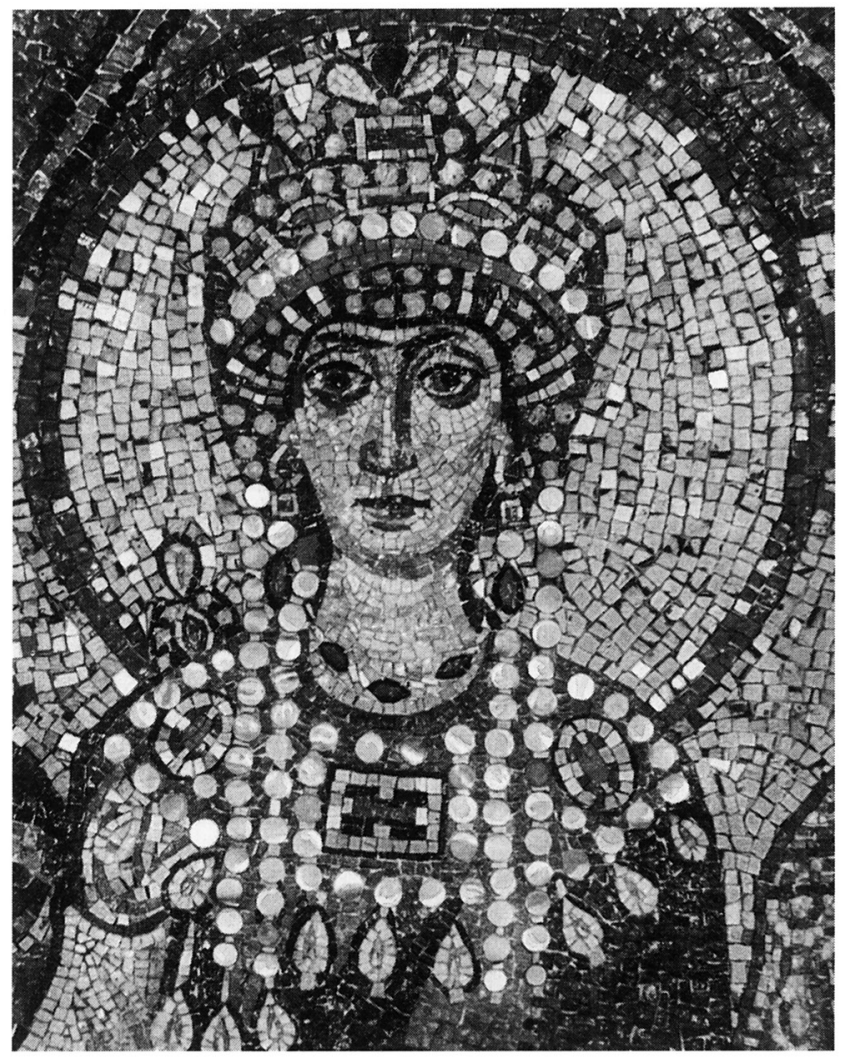

Fig. 4. Kejserinde Theodora med halskæder med vedhæng. (Deichmann 1958, 360).

The Empress Theodora with collar of chains and pendants.

mann 1958). En af mosaikkerne viser den byzantinske kejserinde Theodora med sit følge, og man ser, at halskrave bestående af kæder med vedhæng har hørt til den byzantinske herskerdragt (fig. 4). Mosaikkerne stammer fra 500-årene e.Kr. og i de følgende århundreder danner den byzantinsk inspirede dragt mode såvel ved det frankiske hofmiljø i Europa som ved det russiske hofmiljø i Kiev.

Generelt er gravfund med skålformede spænder forsynet med et mere varieret gravudstyr i 900-årene end i foregående tid, og i flere tilfælde antydes impulser fra fremmede egne (3). Lerchenborgfundet er iøjnefaldende blandt de danske gravfund fra 900-årene ved sit store indhold af østlige importsager.

De skriftlige kilder kan ofte anvendes til at underbygge de arkæologiske kilder, og i nedenstående eksempel gengives araberen Ibn Fadlans beskrivelse af de vikinger, han i 921 mødte på vej op ad Volga-floden, hvortil han var udsendt fra kalifatet i Bagdad (Bæk Simonsen 1981, 52): »Hver kvinde har en lille æske fastgjort på brystet af enten sølv, kobber eller jern, afhængig af hendes mands rigdom. I hver enkelt æske findes en ring, hvortil er knyttet en kniv ligeledes fastgjort til brystet. Omkring halsen har de halskæder af guld eller sølv, thi ægtemanden lader fremstille en halskæde til sin kvinde, når han ejer 10.000 dirham (arabisk møntenhed slået i sølv). Når han ejer 20.000 dirham lader han fremstil- 
le to halskæder og så fremdeles for hver gang han ejer endnu 10.000 dirham. Således er der ofte på en enkelt (kvinde) mange halskæder. Det mest værdifulde smykke hos dem er grønne keramikperler, som findes på skibene. De købslår om dem og betaler en dirham stykket. De trækker dem på en kæde og giver dem til deres kvinder som halskæder«.

Denne skriftlige kilde er naturligvis farvet af araberens personlige indstilling til de skandinavere, han mødte på sin rejse. Alligevel er der flere værdifulde oplysninger, der kan være med til at underbygge de arkæologiske kilder. Her skal fremhæves kædegarnituret og perlerne, som i Østskandinavien var en vigtig del af kvindens dragtudstyr i vikingetiden (Duczko 1985, 11ff). Endvidere kan sociale forskelle ses i Ibn Fadlands beretning, idet mandens sociale status fremgår af kvindens smykkeudstyr.

Både de arkæologiske kilder, billedmateriale og de skriftlige kilder, der er inddraget $\mathrm{i}$ diskussionen om Lerchenborgkvindens dragtudstyr antyder, at smykkerne har tilhørt en kvinde af høj social status, og at hun har fået påvirkning østfra. Det må dog stå åbent, om det er ved slægtsskabsmæssige, handelsmæssige eller politiske kontakter, at de østlige smykker er kommet til Lerchenborg.

\section{NOTER}

1) I Nationalmuseets protokol er genstandene indført 1889 under numrene 6192-6202.

2) Udover Lerchenborg er der registreret 10 sluttede gravfund med perler og skålformede spænder fra 900årene i Danmark (registrering foretaget i 1987 i forbindelse med konferensspeciale).

Sengeløse, Sjælland: 1 skålformet spænde, 4 perler.

Lejre, Sjælland: 2 skålformede spænder, 3 perler.

Trelleborg, Sjælland: 1 skålformet spænde, 2 perler.

Lousgård, Bornholm. 2 skålformede spænder, 41 perler.

Opager, Lolland: 2 skålformede spænder, 4 perler.

Besser By, Samsø: 2 skålformede spænder, 4 perler.

Ballen, Samsø: 1 skàlformet spænde, 1 perle.

Kostrup, Fyn: 2 skålformede spænder, 8 perler.

Kaagården, Langeland: 2 skålformede spænder, 7 perler.

Kjolvejen, Randers: 1 skålformet spænde, 2 perler.

Her adskiller fundet fra Lousgård sig fra de øvrige ved at indeholde 41 perler. Atypisk for samme gravfund er iøvrigt et ligearmet spænde, der normalt hører til 800-årenes dragtudstyr (Becker 1953, 155ff). Der er grund til at opfatte gravfundet som et konservativt eksempel, hvor det foregående århundredes dragtudstyr er kombineret med de typiske skålformede spænder P 51, fra 900-årene.

3) Nævnes skal den rigeste af Fyrkatgravene, grav 4, der bl.a. indeholdt gotlandsk og slavisk import (Roesdahl 1977, 130ff): Dåseformet spænde, to tåringe af sølv, glasperler, perle af kobberlegering, flettet sølvkæde, sølvtrådsring, sølvhængesmykke, stolformet hængesmykke af sølv, rundt hængesmykke af sølvblik og små sølvfragmenter, fragmenter af tungeformet, ornamenteret vedhæng og pind af kobberlegering med guldfolie.

\section{LITTERATUR}

Andersen, M. \& F. Birkebæk. (red.). 1993: Vikingetidens Rusland - Staraja Ladoga og Novgorod. Roskilde Museums Forlag.

Asingh, S. \& A. Kromann. 1992: En vikingetidssølvskat fra Brokhøj, Gjerrild Klint. Kuml 1990, (1992), s. 151-171.

Arbman, H. 1940: Birka I. Die Gräber. Text. K. Vitterhets Historie och Antikvitets Akademien, Uppsala.

Arbman, H. 1943: Birka I. Die Gräber. Tafeln. K. Vitterhets Historie och Antikvitets Akademien, Uppsala.

Arne, T.J. 1934: Das Bootgräberfeld von Tuna in Alsike. K. Vitterhets Historie och Antikvitets Akademien, Stockholm.

Becker, C.J. 1953: Lousgaard 28. Ein Kammergrab des 10. Jahrhunderts aus Bornholm. Acta Archaeologica 24, 155-163. 
Bender Jørgensen, L. 1986: Forhistoriske textiler i Skandinavien. (= Nordiske fortidsminder, serie B, bind 9), København.

Bouchér, F. 1967: A History of Costume in the West. London.

Boyer, M. 1957: Silkevejen. Menneskets mangfoldighed. Kaj Birket Smith (red.). København, s. 174-190.

Brøndsted, J. 1936: Danish Inhumation Graves of the Viking Age. A Survey. Acta Archaelogica 7, s. 81-228.

Callmer, J. 1977: Trade Beads and Bead Trade in Scandinavia ca. 800-1000 AD. Acta Archaeologica Lundensia. Ser. 4. nr. 11, Lund.

Capelle, T. 1968: Der Metallschmuck von Haithabu. Studien zur Wikingischen Metallkunst, Neumünster.

Engelhardt, C. 1881: Jernalderens Gravskikke i Jylland. Aarboger for Nord. Oldk. og Historie, s. 79-184.

Deichmann, F. W. 1958: Frühchristliche Bauten und Mosaiken von Ravenna. Franz Steiners Verlag, Wiesbaden.

Duczko, W. 1985: The Filigree and Granulation Work of the Viking Period. Birka V. Untersuchungen und Studien. Kungl. Vitterhets Historie och Antikvitets Akademien, Stockholm, s. 11-118.

Duczko, W. 1989: Østlig Kontakt. Skalk 1989/4, s. 11-15.

Gjessing, G. 1934: Studier i Norsk Merovingertid. Kronologi og oldsaksformer. Oslo.

Grøn, O., A. Hedeager Krag \& P. Bennike. 1994: Vikingetidsgravpladser på Langeland. Meddelelser fra Langelands Museum.

Hald, M. 1980: Ancient Danish Textiles from Bogs and Burials. A comparative Study of Costume and Iron Age Textiles. (= Archaeological-Historical Series Vol. XXI), Copenhagen.

Hägg, I. 1974: Kvinnodräkten i Birka. (= AUN 2). Uppsala.

Hägg, I. 1984: Birkas orientalska praktplagg. Fornvännen 78, (1983), s. 204-220.

Hägg, I. 1991: Rangsymboliska element i vikingatida gravar. Hedeby-Birka-Mammen. M. Iversen (red.).: Mammen. Grav. kunst og samfund i vikingetid. (= Jysk Arkæologisk Selskabs Skrifter XXVIII), Århus, s. 155162.

Iversen, M. \& U. Näsman. 1991: Mammengravens indhold. M. Iversen (red.).: Mammen. Grav. kunst og samfund i vikingetid. (= Jysk Arkæologisk Selskabs Skrifter XXVIII), Århus, s. 45-66.

Jansson, I. 1985: Ovala Spännbucklor. En studie av vikingatida standardsmycken med utgångspunkt från Björkö-fynden. (= AUN 7), Uppsala.

Johansen, K. Friis. 1912: Sølvskatten fra Terslev. Aarbøger for Nord. Oldk. og Historie. s. 189-264.

Krag, A. Hedeager. 1990: Frankisk-Byzantinsk dragtindflydelse. Kuml 1988-89, s. 347-358.

Krag, A. Hedeager. 1994: Dragtudviklingen fra 8.-10. årh. e.Kr. i Sydskandinavien. Kulturlaget, Lag 5, Moesgård, s. 7-71.

Munksgaard, E. 1974: Oldtidsdragter. Nationalmuseet, København.

Myrdal, J. 1978: Silkevejen - en rejse fra Høje Pamir og Ili gennem Sin-Kiang og Kansu, København.

Neergaard, C. 1892: Jernalderen. Aarbeger for Nord. Oldk. og Historie, s. 207-341.

Nørlund, S. 1948: Trelleborg. (= Nordiske Fortidsminder, IV, 1), København.

Ramskou, T. 1976: Gravfund eller skattefund? Fra Holbak Amt 69, s. 77-87.

Roesdahl, E. 1977: Fyrkat. En jysk vikingeborg. Bd. II. Oldsagerne og gravpladsen, København.

Simonsen, J. Bæk. 1981: Vikingerne ved Volga. Ibn Fadlans rejsebeskrivelse. Resumeret, deloversat og kommenteret. Wormianum, Højbjerg.

Skovmand, R. 1942: De danske Skattefund fra Vikingetiden og den ældste Middelalder indtil omkring 1150. Aarboger for Nord. Oldk. og Historie, s. 1-275.

Steuer, H. 1974: Die Südsiedlung von Haithabu. Studien zur frühmittelalterlichen Keramik im Nordseeküstenbereich und in Schleswig-Holstein. Die Ausgrabungen in Haithabu 6, Neumünster.

Thorvildsen, K. 1957: Ladbyskibet. (= Nordiske Fortidsminder VI, 1), København.

Ørsnes, M. 1966: Form og stil. Nationalmuseets skrifter, Ark.-Historisk række XI. København. 


\section{The Lerchenborg Ornaments Eastern connections in the Viking Age}

New excavations in Russia and new publications of material from Birka in Sweden show how strong was the eastern inspiration of some Danish Viking Age material.

The Lerchenborg find reached the National Museum in 1889, and is regarded as coming from either a hoard or a grave (fig.1). It is a complete set of women's ornaments consisting of the following.

Two tortoise brooches, a rectangular silver brooch, a round silver disc with niello decoration and loop, 3 silver beads and a bead of bronze wire, two doubled up pieces of silver wire each with 3 glass beads on it and another with 1 bead, a "braided" silver cable, 35 beads, 4 coins (two Kufic, one Frankish with loop, and a Scandinavian copy of a Frankish coin). The form and decoration of the tortoise brooches, which accords with type P 51, dates the find to the 10th century A.I. (fig. 2)

The Lerchenborg find differs from other graves with 10 th century tortoise brooches through its many imports. The cable with a coin and other accessories on it may be noted. Seven graves at Birka have produced 14 pendants on braided cables. The silver disc is related in style to the Terslev ornaments. The distribution of these shows concentrations in the SE Scandinavian area with outliers in northern Germany and the Baltic area.

Another unusual feature of the Lerchenborg find is the number of beads, 41 of which are glass or millefiori, and one is carnelian. Carnelian beads are unusual in I)enmark, but a parallel is known from Fyrkat. They are thought to have been manufactured at workshops in Kiev, and their diffusion followed the Russian rivers to northern and central Europe. There are also 4 silver beads. One is oval and decorated with S-shaped filigree coils. Beads of this kind are found mainly in central and eastern Sweden, including Gotland, and in the Baltic states and Russia. A similar ornament combining beads and tortoise brooches comes from grave VI at the Tuna boat-grave cemetery (fig. 3). Two of the Lerchenborg coins are Kufic, the oriental coins imported to Scandinavia especially in the tenth century.
From the above it can be seen that the Lerchenborg find had connections with Sweden and Russia. Near the headwaters of the Iniepr and at the town of Gnezdovo have been found cemeteries with typical Slavic and Scandinavian ornaments, showing a mixture of Russian and Scandinavian culture. The Iniepr flows down to the Black Sea, whence trade proceeded to Constantinople, which was a powerful centre in the 10th century. Constantinople became the focal point of Frankish and Scandinavian trade with the Orient. One of the most important wares was silk, which at first was brought from China along the Silk Road, but later was produced near Constantinople. A number of graves with imported silk have been found at Birka, demonstrating the riches and power of the town's inhabitants. There are no textiles in the Lerchenborg find, but about 3() km away at Slotsbjergby there were found gold thread and textile fragments. Slotsbjerg is close to Trelleborg, which was a centre of power on Zealand in the 10th century. Gold thread and silk are known from half a score of I)anish finds from the 10th century, characteristically containing imported objects. In Jutland choice textile fragments were found at Mammen near Viborg, and at Jelling. From Funen there is the ship-grave from Ladby, whose equipment included some gold-thread ornaments in the form of a sort of buttons for an orientally inspired tunica. These discoveries of choice textile remains are thought to have belonged to the clothing of persons who possessed considerable political and economic power.

This was the environment of the Lerchenborg woman. Her outfit is parallelled on 5th century Byzantine mosaics at Ravenna. An example is the portrait of the Byzantine empress Theodora with her entourage (fig. 4), who is wearing a collar of chains and pendants. In the ensuing centuries Byzantine-inspired dress fashions evolved in courtly environments in both France and Russia, as is supported by Ibn Fadlan's account from 921 in which he described female neckwear. The archaeological material, the pictures, and the written sources 
all suggest that the Lerchenborg woman had a high social status and that she had contacts with the east. It may be left open whether it was for family, commercial, or political reasons that these eastern ornaments reached Lerchenborg.

\author{
Ame Hedeager Krag \\ Institut for Arkaologi og Etnologi, \\ Kobenhavns Universitet
}

Oversattelse: David Liversage 